\title{
VIEWPOINTS
}

\section{The Indicators of Wasatiyyah or Moderation in Islam}

\author{
Mohammad Hashim Kamali*
}

I will begin by posing a question: Are there any indicators to tell us that Islam anchors itself in the middle path of moderation, to show, in other words, that wasatiyyah is the governing principle of Islam?

Islam's advocacy of wasatiyyah is, first of all, known by the explicit affirmation of the Qur'an, when it designates the Muslim community as a community of the middle path (ummatan wasatan) (al-Baqarah, 2:143). This Qur'anic designation is espoused with a commitment for the Ummah to act as witnesses for truth and serve the cause of justice.

Justice is the closest synonym for wasatiyyah, and a great virtue in its own right; it is a major theme of the Qur'an and a principal assignment of government in Islam. Wasatiyyah without justice would be an empty concept, yet justice too must be anchored in wasatiyyah: a judge can be inclined toward severity, or its opposite, and is thus advised to observe moderation in the delivery of justice.

Islam's commitment to the middle path of wasatiyyah is also manifested in mutual recognition (ta'aruf) - Q 49:13). The ummah builds its relationships with other communities and nations in the spirit of ta'aruf that nurtures friendship and peaceful co-existence. One of the manifestations of ta'aruf in Islam is the recognition of Christianity and Judaism as valid religions. Muslim jurists have by analogy extended the same status to the followers of other faiths and communities that reside in Muslim territories, and those who become non-Muslim citizens of a Muslim state.

Another manifestation of the middle path of wasatiyyah in Islam is its recognition of reasonable disagreement (ikhtilaf) in matters of interpretation and opinion. The reality of ikhtilaf in Islam is manifested in the plurality of its juristic and theological schools (madhhabs), such as the Hanafi, Shafi'i, Maliki, and Hanbali - all of which co-exist and have, for the most part, also recognised one another as valid interpretations of Islam. Ikhtilaf thus becomes an aspect of Islamic life and thought and acts as a significant moderator from within. 
In a similar vein, Islam advocates consultation (shura) in matters of community affairs, governance and leadership (Q 3:109 \& 42:38). Shura is a great moderator in that it seeks to give voice, reconcile and reach consensusbased solutions to issues. The Prophet of Islam practiced it most, as did the Orthodox Caliphs (khulafa'Rashidun) after him, thus making shura the principal mode of decision making in public affairs. Consultation is also advised in family relations: the husband, in particular, should consult his wife in family matters and the upbringing of children.

Islam's conception of wasatiyyah is further manifested in its support for dialogue (hiwar) and cooperation (ta'awun) among people in pursuit of beneficial objectives (Q 5:2: "cooperate in good and righteous works, and cooperate not in [pursuit of] hostility and sin"). Dialogue is an Islamic imperative, as is known from the Qur'anic address that engagement and dialogue with the different 'other' must be in the "best and most courteous manner" (16:125), to be conducted in reasonable and persuasive ways leading to better understandings.

Islam also advises moderation in religiosity and the practice of its own duties. The faithful are enjoined to opt for easier ways in the practice of Islam, and that it is God's own illustrious purpose "to lighten your burdens" and "make things easy for you" (Q 4:28; 4:185). Removal of hardship and lightening people's burdens thus become one of the cardinal purposes (maqasid) of Shariah. Hence the ruler, judge and Mufti must opt for easier solutions and fatwas as a matter of priority and preference. The Prophet, pbuh, has advised against excessive fasting, all night vigil, and lengthy prayers that cause fatigue and prove prejudicial to normal family life. He kept his own prayers and sermons, when leading congregations, at moderate length, and instructed others to do the same.

Opting for the middle path is further manifested in Islam's recognition of people's customary practice ('urf). Custom is a recognised basis of law and judgment, which is mentioned in the Qur'an side by side with forgiveness and a certain easiness with people's misgivings: "Take to forgiveness, follow the "urf and turn away from the ignorant" (7:199). People and communities who nurture these values are likely to be practicing wasatiyyah. God praises those "who swallow their anger and forgive others" (Q 3:134) and those who choose to forgive in preference to retaliation and revenge $(2: 178)$.

The middle path is the chosen path of Islam in financial transactions and business relations. This is manifested, in the affirmative sense, in the Shariah laws of commerce and contract which enjoin fair exchange and equivalence in countervalues. Fair exchange is also pursued in the prohibitive injunctions of Shariah on usury (riba), excessive risk-taking and uncertainty in contracts (gharar) and avoidance of morally unethical business transactions. 
Moderation is also advised in the personal lifestyle and character that Islam seeks to nurture among the believers. To this effect, the Qur'an praises those who are peaceful, walk the earth with humility, and are the agents and propagators of peace (25:63). The Prophet added his voice to this, saying: "Every religion has its ethos and the ethos of Islam is modesty - al-haya'."

And lastly, it is a manifestation of Islam's preference for the middle path of moderation that a rich Sufi tradition of spirituality, inner reflection, and a certain distancing of oneself from materialist indulgences has grown throughout the Islamic lands. Sufism is a powerful moderator of dry legalism and obsession with measure-for-measure justice. The Qur'an frequently mentions justice side by side with ihsan (beauty), and Sufism is the nurturing of inner beauty through self-discipline and devotion.

\section{Notes}

* Mohammad Hashim Kamali is the Founding CEO, International Institute of Advanced Islamic Studies (IAIS) Malaysia (Email: ceo@iais.org.my). 